\title{
Landscape structure and live fences in Andes Colombian agrosystems: upper basin of the Cane-Iguaque River
}

Javier Otero ${ }^{1,2} \&$ Miren Onaindia ${ }^{1}$

1. Dept. Plant Biology and Ecology, University of the Basque Country. P.O. Box 64448080 Bilbao, Spain; miren.onaindia@ehu.es

2. Unidad de Sistemas de Información Geográfica. Instituto de Investigación de Recursos Biológicos Alexander von Humboldt. Carrera 13 No. 28-01 Piso 7 Bogotá, Colombia; jotero@humboldt.org.co

Received 04-IV-2008. C Corrected 01-V-2009. Accepted 03-VI-2009.

\begin{abstract}
Changes in land use have generated a new landscape configuration in the Andino orobiome (mountain range) of the tropical Andes, resulting in a mosaic of cultivation and pastures interrupted by small fragments of forest and live fences. This has resulted in an ongoing decrease in the biodiversity of this biome. In the upper basin of the Cane-Iguaque River (Villa de Levya-Boyacá, Colombia), located 2 600-3 000 m above the Cordillera Oriental, over three time periods in 1960, 1984, and 2004, we characterized the structure, patterns, and evolution of the overall landscape and of the live fences (used as tools in biodiversity conservation and considered to be desirable alternatives to nonlive fences in farming production systems) within an agricultural landscape. To do this, we interpreted high-resolution satellite images using a landscape ecology approach and applied landscape map metrics. We found that the natural forests have been transformed by pastures and cultivation, and that although live fences cover only a small portion of the total landscape (4.6\%), they have an important effect on landscape structure and biodiversity. There has been an increase in live fences, especially between 1960 and 1984, as well as an increase in their density. However, there has been a reduction in the average length of live fences over the periods that we studied. This could be due in part to changes in the types of agricultural products that have been cultivated in recent years, with an increase in potatoes and a decrease in other vegetables, and also by resource extraction of timber and fuel wood. In the studied area, agricultural production was sustained while biodiversity conservation was improved by the use of live fences. Therefore, live fences should be considered not only as part of an agriculturally productive area, but also as an important element of a multi-functional landscape that contributes to the maintenance of biodiversity and provides resources of economic and ecological interest, decreasing the pressure on natural forest. Improving the network of live fences constitutes an important strategy for the sustainable management of the rural landscape of the Andino orobiome of Colombia and similar areas in the tropics. Rev. Biol. Trop. 57 (4): 1183-1192. Epub 2009 December 01.
\end{abstract}

Key words: agrosystem, Andes, biodiversity, Colombia, conservation, live fences.

Increasingly, large sections of native tropical forests are being transformed into a mosaic of human-dominated landscapes with scattered remnants of natural and secondary forests (Etter et al. 2005). Andean ecosystems are among the most diverse and threatened ecosystems in the world (Etter and Villa 2000), but it is needed more data regarding the extent of the impact of the transformation processes that have affected these ecosystems.

The substitution of original forest systems by large grassland expanses in mountainous regions has brought about high levels of erosion, biodiversity loss, water pollution, and cultural loss. In biologically mega-diverse countries that are undergoing rapid manmade 
landscape transformation, it is important to understand and model the patterns of land cover change (Etter et al. 2006).

The promotion of farming production models has generally led to landscapes dominated by a matrix of fields with a few dispersed trees. There are, however, production models that are compatible with biodiversity conservation, such as systems that maintain live fences. These can offer benefits, such as environmental services, to the production systems in which they are found.

Live fences are lineal vegetation elements that may be natural remnants of the original forest or planted to delineate property or act as wind and firebreaks (Küppers 1992, Molano et al. 2003). They are common elements in neotropical agricultural landscapes and may play important roles in biodiversity conservation by enhancing landscape connectivity. However, little is known about their abundance and spatial arrangement (Leon and Harvey 2006). Connectivity is a key concept in landscape ecology, as it relates to the flows and movements of organisms as driven by the landscape structure (Burel and Baudry 2005). Live fences act as corridors of movement and dispersal for many forest species such as carabids (ground beetles), small mammals, and plants, and they often increase the functional connectivity of rural landscapes (Burel 1996). In addition to reducing exploitation of the original forest, live fences are both aesthetically pleasing and beneficial for fauna (birds and honeybees) (Budowski 1993).

Live fence composition and floristic structure depends on the ecological conditions, the history of management, and the production system used in the regions in which they are found. Studies undertaken in Central America refer to the use of more than hundred species in the establishment of live fences, although only some fifteen species are in general use. Among the most common species are Spondias purpurea and Yucca elephantipes, which produce edible fruits and flowers; the medicinal plant Bursera simaruba; and species of the genus Cordilyne, which provide firewood (Harvey et al. 2003).
The present study is a pioneering investigation of the live fences of the Colombian Andes. The objectives of this study were: (1) to characterize the structure, patterns, and evolution of the landscape and the use of live fences in an agricultural landscape in the Colombian Andean mountains and (2) to analyze the presence of live fences as tools in biodiversity conservation and as desirable alternatives in farming production systems.

\section{MATERIALS AND METHODS}

Study site: The study area is located in the upper basin of the Cane-Iguaque River (Villa de Levya-Boyacá.). An area of 2500 ha within the eastern cordillera of the Colombian Andes was studied, in a region of farming landscape associated with the traditional use of live fences. The traditional uses include the planting of fences, and the area is located within the great ecosystem of the Altiplano Cundiboyacense, in humid Andes forest life zones

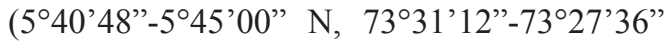
W). Ecologically, the region is located within the Andino orobiome of the Eastern Cordillera, which is one of the most representative biomes of the Colombian Andes (Rodríguez et al. 2004). The entire study region is in the Andean cold and humid bioclimate, lying at an altitude of 2600-3000 m and comprising an undulating landscape interspersed with hillsides occupying $12 \%-25 \%$ of the area.

The natural vegetation of the upper basin of the Cane-Iguaque River is composed of dense, tropical Andean forests, which are highly biologically diverse ecosystems (Rodríguez et al. 2004).

The main production system is extensively dual purpose: grazing (meat and milk) and cultivation (potato, beans, vegetables, onions, and fruit). The size of the cultivated areas in this region are a function of the distribution of ownership; a large percentage are less than 2 ha and part of that is turned over to pasture. The most traditional practice however, is the rotation of land between cultivation and pasture, in accordance with the Plan de Ordenamiento 
Territorial of Alcaldía de Villa de Leyva. In addition, the types of crops being cultivated have changed, with a trend toward increased potato plantings and reduced vegetable plantings, such that the total area of potato fields is larger than that of the vegetable fields.

Analysis of the landscape structure and evolution: We mapped the territory to the scale of 1:25000 in the years 2004, 1984, and 1960 . The mapping work required the use of highresolution, remote sensor images, aerial photographs, and SPOT satellite images. The base map at the 1:25000 scale was from the Instituto Geográfico Agustín Codazzi (IGAC.) This mapping was complemented by information from NIMA (National Imagery and Mapping Agency) in the Raster $15 \mathrm{~m}$ resolution format (1997). The interpretation and digitalization of the base and thematic (cover and live fences) mapping was undertaken using geographic information system tools and with the help of geographic information system (GIS) programs (ArcView, ERDAS IMAGINE, and ArcGis). The process followed guidelines laid down in the development of the map of Colombian Andes ecosystems (Rodríguez et al. 2004). The information was completed by fieldwork with geo-referencing by means of global positioning system (GPS).

From these data, we calculated the landscape indices using the FRAGSTATS programme (McGarigal et al. 2002). For each type of ecosystem, the indices calculated were the following: total area (CA), mean patch size (MPS), number of patches (NP), patch density (PD), mean patch fractal dimension (MPFD), and form index (SHAPE).

PD was calculated using the formula: PD $=100 \times \mathrm{NP} / \mathrm{ST}$, where $\mathrm{NP}=$ number of patches and TS $=$ total study area in hectares (McGarigal et al. 2002). The fractal dimension (FD) provided us with information about the shape of the patch.

For calculating the FD of each patch, the formula $\mathrm{FD}=2 \ln \mathrm{P} / \ln \mathrm{A}$ was used, where $\mathrm{A}=$ area of each patch in $\mathrm{m}^{2}$, and $\mathrm{P}=$ perimeter in meters (McGarigal et al. 2002). The value of this index was understood to be between 1 and 2. Values near 1 indicated very simple perimeters, such as circles or squares, while values nearer 2 indicated complex, jagged perimeters.

For calculating the SHAPE, the formula SHAPE $=\mathrm{P} /(2 \sqrt{\mathrm{A}} \varpi)$ was used, where $\mathrm{A}=$ area of the patch in $\mathrm{m}^{2}$ and $\mathrm{P}=$ perimeter in meters (McGarigal et al. 2002). The value of this index was equal to 1 when the patch wa circular, and increased without limit as the shape of the patch became more irregular.

To compare the medians of the index values among the different time periods studied, the Kruskal-Wallis and Man-Whitney tests were used, using SPSS software (Siegel and Castellan 1988).

\section{RESULTS}

Landscape structure: The distribution of the ecosystem types demonstrates that more than $98 \%$ of the area studied has been transformed with respect to the original land cover. The humid Andean forest, in which the Andean oak (Quercus humboldtii) predominates, occupied only 44.65 ha $(1.79 \%$ of the area), and secondary forest with 197.57 ha occupied some $7.94 \%$ of the area. The natural forests were of a dispersed nature, in the form of relics, and were mainly found in the higher regions with steep slopes, and in some areas of the lower zone. The live fences occupied 115.71 ha and composed $4.65 \%$ of the region. The fences comprise mostly native species (e.g., Alnus acuminata, Quercus humboldtii, and Viburnum triphyllum), and only a few exotic species, such as eucalypts, pines, and cypress were used in the establishment of the planted fences. The areas of pasture and cultivation were more than $50 \%$ of the region (Fig. 1). The principal transformed ecosystems present in the region were pasture $(41.77 \%$ of the area), the forest grazing system $(4.94 \%)$, areas consisting predominantly of secondary scrub $(24.96 \%)$, and cultivated areas $(9.92 \%)$. Additionally, 3.42\% of the region was occupied by forest plantations (Table 1). 


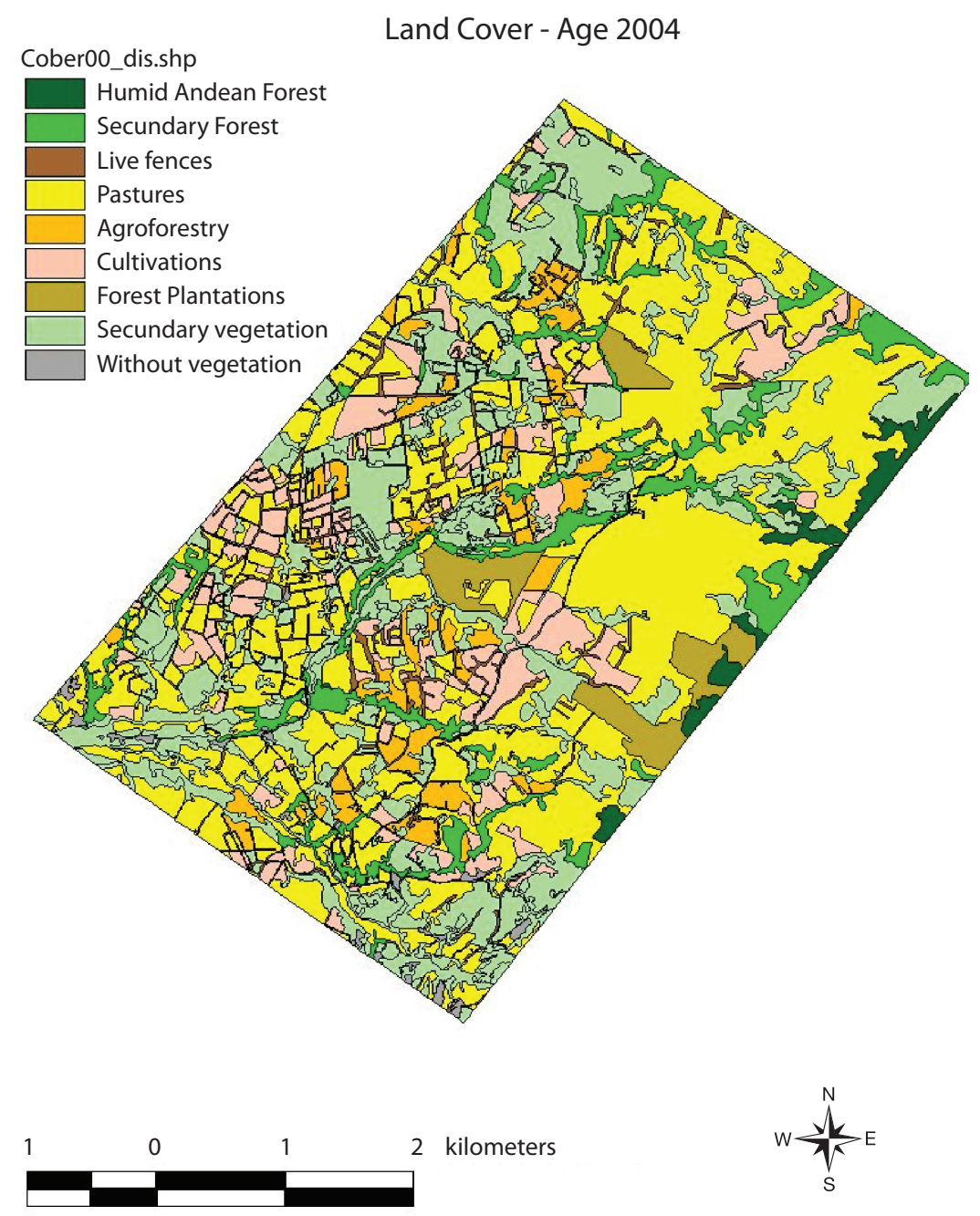

Fig. 1. Vegetation coverage map for 2004 in the Cane-Igaque region.

Fig. 1. Cobertura vegetal para el año 2004 en la región Cane-Igaque.

The region displayed a high degree of fragmentation, with a total of 1254 patches, including 245 pasture patches, of which 117 were cultivated and 56 were of natural and secondary forests. The greatest number of patches consisted of live fences (292), which also had the greatest density (11.8), and corresponded to the highest values. The lower densities corresponded to the forests, and the lowest densities corresponded to the natural forests. The average size of the patches was low in general, with elevated deviation values with respect to the value of the average (high standard errors); the live fences had the smallest average sizes at 0.39 ha. The highest values of the fractal dimension indices were seen in the live fences and secondary forests, which were very irregular in form. Meanwhile, the cultivated areas and the pastures were more regularly shaped (Table 2). 
TABLE 1

Ecosystems of the Cane-Iguaque region for 2004

CUADRO 1

Ecosistemas de la region Cane-Iguaque para el 2004

$\begin{array}{lcc}\text { Ecosystem type } & \text { Area (ha) } & \text { Area (\%) } \\ \text { Humid Andean forest } & 44.65 & 1.79 \\ \text { Secondary forest } & 197.57 & 7.94 \\ \text { Live fences } & 115.71 & 4.65 \\ \text { Pastures } & 1039.96 & 41.77 \\ \text { Agroforestry } & 122.91 & 4.94 \\ \text { Cultivations } & 246.88 & 9.92 \\ \text { Forest plantations } & 85.03 & 3.42 \\ \text { Secondary vegetation } & 621.43 & 24.96 \\ \text { Without vegetation } & 15.71 & 0.63\end{array}$

Landscape evolution: When we examined the evolution of coverage resulting from different land uses in 1960, 1984, and 2004, we found that, generally, all coverage types had changed over time, but at a greater magnitude in the natural forests, the pastures, and the secondary scrub. The natural forests had diminished by nearly 160 ha $(6.4 \%$ of the total area, or $77.9 \%$ of the forest area in 1960) and the secondary scrub had grown by 168.9 ha or $6.75 \%$ of the total area (Table 3 ).

The most dramatic changes took place between 1984 and 2004; the natural forest lost $123 \mathrm{ha}$, the cultivated areas $105 \mathrm{ha}$, and

TABLE 2

Landscape indices for the different ecosystems: number of patches, patch density, patch size (mean), patch fractal dimension (mean), and patch shape index

\section{CUADRO 2}

Índices de paisaje para los diferentes ecosistemas: número de parches, densidad de parches, tamaño de parches (media), revisión de la dimensión "fractal" (media), e indice de forma del parche

$\begin{array}{lccccc}\text { Landscape indices } & \text { Forest } & \text { Secondary forest } & \text { Live fences } & \text { Pastures } & \text { Cultivations } \\ \text { Number of patches } & 7 & 49 & 292 & 245 & 117 \\ \text { Patch density }(* 100 \text { ha) } & 00.28 & 10.96 & 11.84 & 97.91 & 46.76 \\ \text { Patch size (ha) } & 60.42 & 40.03 & 00.39 & 40.24 & 20.11 \\ \text { Patch fractal Dimension } & 10.11 & 10.17 & 10.19 & 10.10 & 10.09 \\ \text { Patch shape Index } & 10.70 & 20.12 & 10.89 & 10.56 & 10.52\end{array}$

TABLE 3

Evolution of coverage of ecosystems in the Cane-Iguaque region for the time periods analyzed: 1960, 1984, and 2004

CUADRO 3

Evolución de la cobertura de los ecosistemas en la región de Cane-Iguaque de los periodos analizados: 1960, 1984 y 2004

\begin{tabular}{|c|c|c|c|c|c|c|}
\hline \multirow{2}{*}{ Ecosystems } & \multicolumn{2}{|c|}{1960} & \multicolumn{2}{|c|}{1984} & \multicolumn{2}{|c|}{2004} \\
\hline & Area (ha) & $\%$ & Area (ha) & $\%$ & Area (ha) & $\%$ \\
\hline Humid forest & 204.83 & 8.23 & 168.64 & 6.77 & 44.65 & 1.79 \\
\hline Secondary forest & 88.47 & 3.55 & 108.41 & 4.35 & 197.57 & 7.94 \\
\hline Live fences & 113.86 & 4.57 & 127.13 & 5.11 & 115.71 & 4.65 \\
\hline Pastures & 994.54 & 39.95 & 1025.08 & 41.17 & 1039.96 & 41.77 \\
\hline Agroforestry & 95.45 & 3.83 & 112.18 & 4.51 & 122.91 & 4.94 \\
\hline Cultivations & 341.67 & 13.72 & 359.56 & 14.44 & 246.88 & 9.92 \\
\hline Forest plantations & 29.77 & 1.20 & 29.77 & 1.20 & 85.03 & 3.42 \\
\hline Secondary vegetation & 610.52 & 24.52 & 546.36 & 21.94 & 621.43 & 24.96 \\
\hline Without vegetation & 10.52 & 0.42 & 12.46 & 0.50 & 15.71 & 0.63 \\
\hline
\end{tabular}


the secondary scrub 78 ha, while pastures and scrub increased by 196 ha and secondary forest increased by $97 \mathrm{ha}$. In accordance with the spatial comparison, the changes in the natural forest were towards secondary forest and scrub and, in a lesser proportion, to pasture. Similarly, the zones that were dedicated to cultivation had been replaced by scrub and pasture.

From 1960 to 1984 , there was an increase in live fences of 13 ha, while from 1984 to 2004, they decreased by 6 ha. The changes in live fence areas are seen more clearly when presented in terms of units and length, and are presented below.

Temporal analysis of the live fences: In 2004, live fence coverage comprised 642 fences with a length of $126.43 \mathrm{~km}$ over the study area, while in 1984, 577 fences covered 135.64 $\mathrm{km}$. In 1960, there were $70.68 \mathrm{~km}$ of live fences comprising 249 units (Table 4).

In 1960, the presence of live fences was in its early stages, compared with the other two analysis periods; however, this first cartographic evidence demonstrates the importance of live fences in landscape management in the study region. In the following two decades, this coverage increased by more than $64 \mathrm{~km}$ of fences and approximately 328 new units, which corresponds to a net increase of $92 \%$ in length and some $132 \%$ in quantity (Fig. 2). In 2004 , however, the coverage of live fences was slightly reduced in length $(7 \%)$, but increased in number (11\%) (Table 4). The most common length of live fences found in this study was in the 100-200 $\mathrm{m}$ range. The second frequent fence

TABLE 4

Number of patches, total length, mean patch length, and density of live fences for the studied periods

CUADRO 4

Número de parches, longitud total, longitud media de parches, y la densidad de cercas vivas para el período estudiado

$\begin{array}{cccccc}\text { Year } & \text { Number of patches } & \begin{array}{c}\text { Total length } \\ (\mathrm{km})\end{array} & \begin{array}{c}\text { Mean patch length } \\ (\mathrm{m})\end{array} & \begin{array}{c}\text { Density } \mathrm{n}^{\circ} / \mathrm{ha} \\ \text { Density }(\mathrm{m} / \mathrm{ha})\end{array} \\ 1960 & 249 & 70.68 & 283.9 \pm 15.8^{*} & 0.10 & 28.2 \\ 1984 & 577 & 135.64 & 235.1 \pm 7.1^{*} & 0.23 & 54.2 \\ 2004 & 642 & 126.43 & 196.9 \pm 5.2^{*} & 0.26 & 50.6\end{array}$

* Significant differences (Mann-Whitney $\mathrm{p}<0.05$ )

* Diferencias significativas (Mann-Whitney $\mathrm{p}<0.05$ )
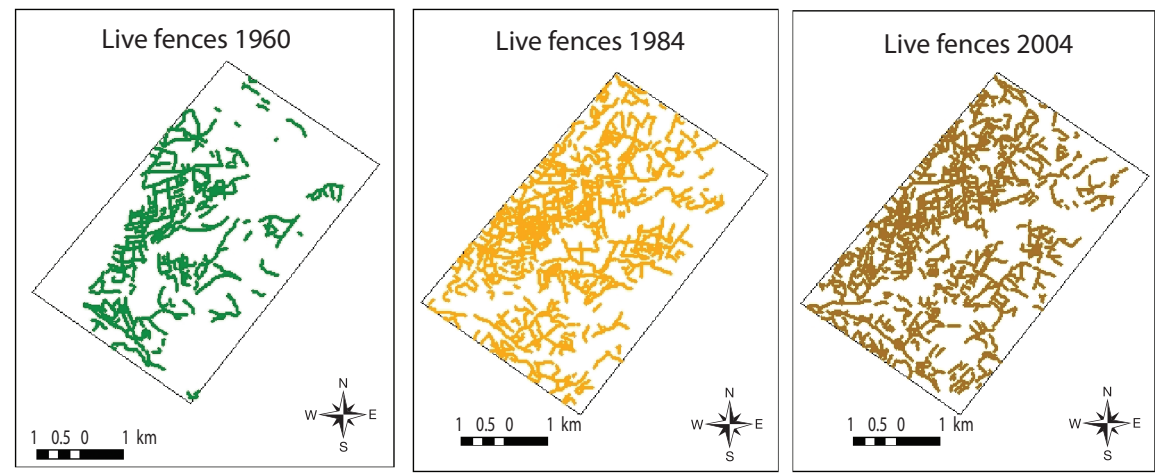

Fig. 2. Coverage of live fences in the three study time periods (1960, 1984, and 2004).

Fig. 2. Cobertura de cercas vivas en los tres períodos de tiempo de estudio (1960, 1984 y 2004). 
length was in the 200-300 m range (Fig. 3). The difference in length between these two groups was significant (Kruskall-Wallis $\mathrm{p}<0.05$ ), with an average in 1960 of $284 \mathrm{~m}$, in 1984 of $235 \mathrm{~m}$, and in 2004 of $197 \mathrm{~m}$. There were also significant differences in fence lengths between 1984 and 2004 (Man-Whitney $\mathrm{p}<0.05$ ). The evolution of live fences in the study region is of great importance, due to their increase in magnitude (length and area), particularly in the period between 1960 and 1984, and in their units number and distribution in the landscape. In terms of density by number, in 1960 there were 0.09 live fences/ha, increasing to 0.23 live fences/ha by 1984 . In 2004, there were 0.26 live fences/ ha. The density (in $\mathrm{m} / \mathrm{ha}$ ) also changed over time, increasing from $0.028 \mathrm{~km} / \mathrm{ha}$ in 1960 to $0.05 \mathrm{~km} / \mathrm{ha}$ in 2004 (Table 4).

\section{DISCUSSION}

Anthropogenic activities over hundreds of years have transformed the natural ecosystem in the basin that we studied. More than $98 \%$ of the natural coverage has been lost, and a complex landscape has been formed. This transformation has brought about a fragmentation of the natural coverage and loss of flora and fauna biodiversity due to the reduction of food and habitat for many species (Thenail 2002, Baudry et al. 2003).

The region is currently used mostly for grazing, and is composed mainly of pasture and scrub cover. The actual landscape configuration is a mosaic of covers, and more than $50 \%$ of the land area is dominated by pasture, cultivation, and secondary scrub, which are separated by live fences (like lines) and secondary forests with a very fragmented distribution. The average patch size of forest is smaller when compared with other converted Colombian lowland ecosystems (Etter et al. 2006).

The loss of natural forest over the last 40 years is significant, and has been accompanied by fragmentation and a reduction in the size of the forest patches. Between 1960 and 2004, natural forests gave way to secondary forest (for timber extraction) and pasture, as

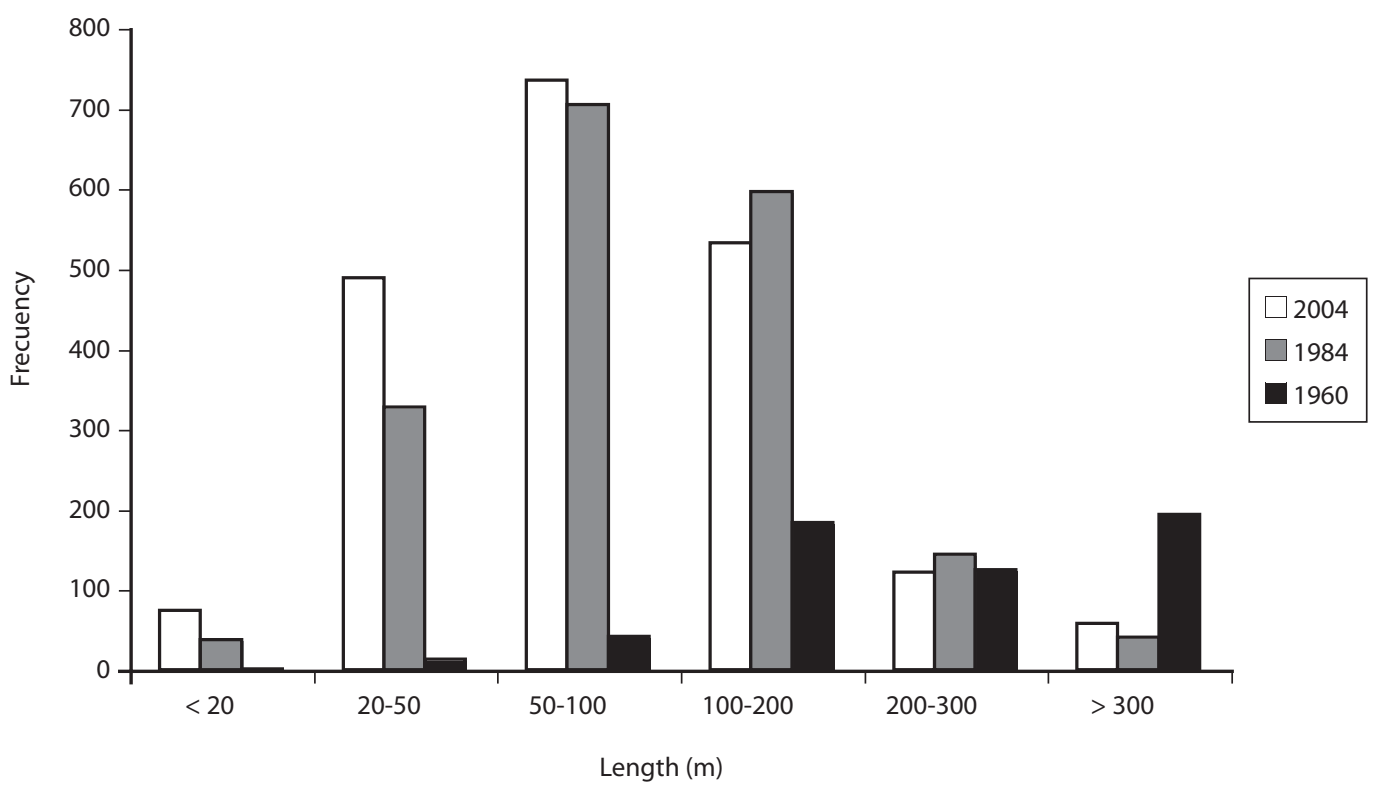

Fig. 3. Distribution of live fences ranked by length during the studied periods (1960, 1984, and 2004).

Fig. 3. Distribución de cercas vivas clasificadas por longitud en los tres períodos de tiempo de estudio (1960, 1984 y 2004). 
well as to forest plantations. What stand out among the landscape elements are the live fences, which allow for continuity between the natural and semi-natural ecosystems, and mitigate the impact of production systems on these ecosystems. Although live fences cover only a small area of the total landscape (4.6\%), their spatial distribution is important, and they have a positive effect on landscape structure and biodiversity.

In the study area, there is a cultural tradition of using live fences for different reasons: property separation, separating zones of pasture and cultivation, timber and firewood resources, and other uses, including medicinal and ornamental (Cárdenas 2005). Additionally, land use changed to more efficient production forms for small holdings, such as semi-housed dairy farming, or the cultivation of potatoes and vegetables. To separate these holdings, live fences are used (Castellanos 2005). In association with this, there has been an increase in the partitioning of properties and production units (especially grazing); by tradition, separations have been made using rows of forage trees as live fences. The live fences originally arose from natural forest remnants, but they are now planted (one or two rows of exotic shrubs or trees), and the flora structure and composition has changed (Suárez 2005).

There has been an increase in live fences, especially between 1960 and 1984, as well as an increase in their density. Generally, this has been high, compared with other regions in Colombia (Murgueitio et al. 1999), Costa Rica (Leon and Harvey 2006), Central America (Harvey et al. 2006, Budowski 1993), and Europe (Forman and Baudry 1984, Thenail and Baudry, 2004). The increase in live fences in this zone can be explained in part by the partition of land property and by local reforestation projects (Cárdenas 2005).

There has been, however, a reduction in the length of live fences over the period that we studied. This could be due in part to a tendency to change the type of cultivation in recent years, with an increase in potato crops and a decrease in vegetable crops. Implicit in this is the necessity of larger cultivation parcels, and the consequent elimination of fragments of fences. This reduction can also be explained by the extraction of certain resources from live fences, such as timber and firewood, which could be reducing the pressure on natural and secondary forests.

The primary ecological roles of live fences are to provide habitat and resources for animal species and to provide the structural connectivity of woody habitat across the agricultural landscape (Harvey et al. 2003). On the other hand, the trees of the fences are utilized for firewood, timber, and food (Castellanos 2005). Additionally, they can be used to avoid erosion, retain soil humidity. They also slow run-off, act as windbreaks, and provide useful, rapidgrowing timber species (Burel 1992).

The Andino orobiome of the Eastern Cordillera is rich in biodiversity, and, by its location, provides connectivity between the different altitudes of the Paramo and Subandino biomes (Rodriguez et al. 2004). The study area, located in this biome, is considered to be strategically important for biodiversity conservation, and to conform a balance between conservation and agricultural use. Both connectivity and functional ecosystems are facilitated by a network of live fences, which allow the area to serve as a multifunctional landscape where both production and conservation can be pursued successfully.

In some Central American countries, such as Costa Rica (Harvey 2000) and Nicaragua (Pagiola et al. 2007, Esquivel et al. 2008), live fences are widely used to promote sustainable agriculture. This very promising sustainable practice deserves more research and dissemination (Budowski and Russo 1993). Live fences have been increasing in the study area, and they are contributing to connectivity and other ecological and environmental functions without affecting agriculture or grazing production, which has grown in the last decade (Alcaldía de Villa de Leyva 2001). There is, however, potential to increase the network of live fences in the region, with greater possibilities for 
connectivity (Cárdenas 2005, Baudry et al. 2003, Thenail 2002).

Live fences are important features of agricultural landscapes that merit much greater attention in sustainable land management strategies. They need to be an explicit element in regulations and incentives that aim to enhance the ecological integrity of rural landscapes in Central America (Harvey et al. 2003). Agricultural landscapes should be included in strategies to ensure the maintenance of tree diversity, as has been proposed for other areas of the neotropics (Merlos et al. 2005).

The results of our study contribute to the knowledge of live fences, and their roles in production, conservation, and cultural land use. This study was a preliminary examination of some of the processes that occur in agroecosystems, and we hope that live fences and connectivity in the neotropics will be the subject of future basic and applied research in biology, ecology, and agronomy. Our results should be supplemented with research regarding the composition of live fences, with special attention to those plant species that will serve best to conserve a wide variety plants and birds, and will generate further conservation and production services within the Cane-Iguaque river basin.

Similarly, our results can be taken into account during the planning process for land use, and development, and while preparing policies to improve sustainable agricultural development in the study area.

\section{RESUMEN}

El cambio del uso del suelo ha generado una nueva configuración del paisaje en el Orobioma Andino de los Andes tropicales, dando lugar a un mosaico de cultivos y potreros interrumpidos por pequeños fragmentos de bosque y cercas vivas, con la disminución sobre la biodiversidad de este bioma. En la cuenca alta del río Cane-Iguaque (Boyaca-Colombia), ubicada entre 2 600-3 000 metros de altitud sobre la cordillera Oriental, se realizó un estudio de caracterización de estructura, patrones y evolución del paisaje y de las cercas vivas, en tres periodos 1960 , 1984 y 2004, como herramienta para la conservación de la biodiversidad y alternativa en el manejo de los sistemas agrícolas. Se utilizó una metodología de interpretación de imágenes de satélite de alta resolución, bajo el enfoque de la ecología del paisaje y la utilización de métricas del paisaje. El bosque original esta altamente transformado por pastizales y cultivos, las cercas vivas ocupan apenas el $4.6 \%$ del área de estudio pero por su distribución se constituyen en elementos importantes para la biodiversidad. Se observa un incremento en las cercas vivas, entre los años 1960 y 1984. Sin embargo en este mismo período se da una disminución en la longitud, debido a la tendencia de aumento en el cultivo de papa y por la extracción de recursos de madera y leña. Para la zona de estudio es muy importante la producción agrícola y la conservación de la biodiversidad, y puede ser mejorada mediante la utilización de cercas vivas. Por tanto, las cercas deben considerarse como elementos multifuncionales del paisaje que contribuyen en el mantenimiento de la biodiversidad y aportan recursos de interés ecológico y económico, atenuando la presión sobre los bosques originales. El manejo adecuado y la mejora de la red de cercas vivas se constituyen en estrategias importantes para la gestión sostenible de paisaje rural de la zona andina colombiana.

Palabras clave: agro-sistema, Andes, biodiversidad, cercas vivas, conservación, Colombia.

\section{REFERENCES}

Baudry J., F. Burel, S. Aviron, M. Martin, A. Ouin, G. Pain \& C. Thenail. 2003. Temporal variability of connectivity in agricultural landscapes: Do farming activities help? Landsc. Ecol. 18: 303-314.

Budowski, G. 1993. The scope and potential of agroforestry in Central-America. Agrofores. Syst. 2: 121-131

Budowski, G. \& R.O. Russo. 1993. Live fence posts in Costa Rica: a compilation of the farmer's beliefs and technologies. J. Sustain. Agr. 3: 65-87.

Burel, F. 1992. Effect of Landscape Structure and Dynamics on Species Diversity in Hedgerow networks. Landsc. Ecol. 6: 161-174.

Burel, F. 1996. Hedgerows and their role in agricultural landscapes. Crit. Rev. Plant Sci. 15: 169-190.

Burel, F. \& J. Baudry. 2002. Ecología del Paisaje. Conceptos, Métodos y Aplicaciones. Ediciones Mundi Prensa, Madrid, España.

Burel, F. \& J. Baudry. 2005. Habitat quality and connectivity in agricultural landscapes: the role of land use systems at various scales in time. Ecol. Indicat. 5: 305-313.

Cárdenas, F. 2005. Percepción cultural de cercas vivas en cuatro zonas de los andes colombianos. Instituto de Investigación de recursos biológicos Alexander von 
Humboldt. Programa uso y valoración de la biodiversidad. Bogotá, Colombia.

Castellanos, L. 2005. Diagnóstico de sistema de uso de biodiversidad: informe final. Instituto Alexander von Humboldt. Bogotá, Colombia.

Esquivel, M.J., C.A. Harvey, B. Finegan, F. Casanoves \& C. Skarpe. 2008. Effects of pasture management on the natural regeneration of neotropical trees. J. Appl. Ecol. 45: 371-380.

Etter, A. \& L.A. Villa. 2000. Andean forests and farming systems in part of the Eastern Cordillera (Colombia). Mt. Res. Dev. 20: 236-245.

Etter, A., C. McAlpine, D. Pullar \& H. Possingham. 2005. Modeling the age of tropical moist fragments in heavily-cleared lowland landscape of Colombia. Forest. Ecol. Manag. 208: 249-260.

Etter, A., C. McAlpine, D. Pullar \& H. Possingham. 2006. Modelling the conversion of Colombian lowland ecosystems. J. Environ. Manag. 79: 74-87.

Forman, R.T.T \& J. Baudry, 1984. Hedgerows and hedgerow networks in landscape ecology. J. Environ. Manag. 8: 495-510.

Harvey, C.A. 2000. Colonization of agricultural windbreaks by forest trees: effects of connectivity and remnant trees. Ecol. Appl. 6: 1762-1773.

Harvey, C.A., C. Villanueva, J. Villacis, M. Chacón, D. Muñoz, M. López, M. Ibrahim, R. Gómez, R. Taylor, J. Martínez, A. Navas, J. Sáenz, D. Sánchez, A. Medina, S. Vilchez, B. Hernández, A. Pérez, F. Ruiz, F. López, I. Lang, S. Kunth \& F.L. Sinclair, 2003. Contribución de las cercas vivas a la productividad e integridad ecológica de los paisajes agrícolas en América Central. Agroforestería en las Américas 10: 30-39.

Harvey, C.A., C. Villanueva, J. Villacis, M. Chacón, D. Muñoz, M. López, M. Ibrahim, R. Gómez, R. Taylor, J. Martínez, A. Navas, J. Sáenz, D. Sánchez, A. Medina, S. Vilchez, B. Hernández, A. Pérez, E. Ruiz, F. López, I. Lang \& F.L. Sinclair, J.T. 2005. Contribution of live fences to the ecological integrity of agricultural landscapes. Agr. Ecosyst. Environ. 11: 200-230.

Küppers, M. 1992. Changes in plant ecophisiology across a central European hedgrow ecotone. In: Hansen, A.J. \& F. Di Castri (eds.). Lanscape Boundaries: consequences for biotic diversity and ecological flows. Springer, Berlin, Germany.

Leon, M.C. \& C.A. Harvey. 2006. Live fences and landscape connectivity in a neotropical agricultural landscape. Agroforest. Syst. 68: 15-26.
McGarigal, K. \& B. D. Marks. 1995. Fragstats: spatial pattern analysis program for quantifying landscape structure. United States Department of Agriculture, Forest Service, General Technical Report PNW-351.

Murgueitio, E., M. E. Gómez, M. Rosales \& M. Maurucio. 1999. Agroforestería para la producción animal sostenible. Centro para la Investigación en Sistemas Sostenibles de Producción Agropecuaria (CIPAV), Cali, Colombia.

Merlos, D.S., C.A. Harvey, A. Grijalva, A. Medina, S. Vilchez \& B. Hernandez. 2005. Vegetation diversity composition and structure in a cattle agro-landscape of Matiguas, Nicaragua. Rev. Biol. Trop. 53: 387-414.

Molano, J.G., M.P. Quiceno \& C. Roa. 2003. El papel de las cercas vivas en un sistema agropecuario en el piedemonte llanero, p. 45-63. In Sánchez, M.D. \& M. Rosales (eds.). Agroforestería para la producción animal en América Latina-II. Dirección de Producción y Sanidad Animal, FAO. Roma, Italia.

Pagiola, S., E. Ramirez, J. Gobbi, C. De Haan, M. Ibrahim, E. Murgueitio \& J.P. Ruiz. 2007. Paying for the environmental services of silvopastoral parctices in Nicaragua. Ecol. Econ. 64: 374-385.

Rodríguez, N., D. Armenteras, M. Morales \& M. Romero. 2004. Ecosistemas de los Andes colombianos. Instituto de Investigación de Recursos Biológicos Alexander von Humboldt. Bogotá, Colombia.

Siegel, S. \& N. J. Castellan. 1988. Nonparametrics statistics for the behavioral sciences. McGraw \& Hill, New York, USA.

Suárez L. S. 2005. Evolución y configuración del paisaje ganadero con el fin de formular alternativas de uso sostenible asociadas a cercas vivas y remanentes de vegetación natural en cuatro zonas de los Andes colombianos: estructura, composición florística y uso de los cercos vivos en la cuenca Cane-Iguaque (Boyacá-Colombia). Instituto de investigaciones de recursos biológicos Alexander Von Humboldt, Bogotá, Colombia.

Thenail, C. 2002. Relationships between farm characteristics and the variation of the density of hedgerows at the level of a micro-region of bocage landscape. Study case in Brittany, France. Agric. Syst. 71: $207-$ 230 .

Thenail, C. \& J. Baudry. 2004. Variation of farm spatial land use pattern according to the structure of the hedgerow network (bocage) landscape: a case study in northeast Brittany. Agric. Ecosyst. Environ. 101: 53-72. 